\title{
Isoliquiritigenin suppresses human T Lymphocyte activation via covalently binding cysteine 46 of IKB kinase
}

\author{
Fenggen Yan ${ }^{1}$, Fen Yang ${ }^{1}$, Rui Wang ${ }^{1}$, Xiao Jun Yao ${ }^{1}$, Liping Bai ${ }^{1}$, Xing Zeng ${ }^{2}$, JiaJun \\ Huang ${ }^{1}$, Vincent Kam Wai Wong ${ }^{1}$, Christopher Wai Kei Lam ${ }^{1}$, Hua Zhou ${ }^{1}$, Xiaohui Su${ }^{1}$, \\ Juan Liu' ${ }^{1}$, Ting Li $^{1}$, Liang Liu ${ }^{1}$ \\ ${ }^{1}$ State Key Laboratory of Quality Research in Chinese Medicine/Macau Institute for Applied Research in Medicine and Health, \\ Macau University of Science and Technology, Macau, China \\ ${ }^{2}$ Guangdong Provincial Academy of Chinese Medical Sciences, Guangzhou, China \\ Correspondence to: Liang Liu, email: Iliu@must.edu.mo \\ Ting Li, email: tli@must.edu.mo
}

Keywords: isoliquiritigenin, IKK 3 , cysteine 46, T lymphocyte, immune-suppression

Received: February 25, 2016

Accepted: July 27, 2016

Published: September 10, 2016

Copyright: Yan et al. This is an open-access article distributed under the terms of the Creative Commons Attribution License (CC-BY), which permits unrestricted use, distribution, and reproduction in any medium, provided the original author and source are credited.

\section{ABSTRACT}

The efficacious practice of precision personalized medicine requires a more exact understanding of the molecular mechanisms of drug, hence then it is necessary to identify the binding site of the drugs derived from natural sources. In the study, we investigated the suppressive effect and underlying mechanism of isoliquiritigenin $\left(2^{\prime}, 4^{\prime}, 4\right.$-trihydroxychalcone; ILG), a phyto-flavonoid, on human T lymphocyte activation in vitro and in vivo. The results showed that ILG dose-dependently suppressed human $T$ cell activation via suppressing IKBa phosphorylation and degradation, NF-KB nuclear translocation and IKK $\beta$ activity. Molecular docking results predicted that cysteine 46 (Cys-46) is probably the binding site of ILG on IKK $\beta$, and this prediction has been validated by competition assay and kinase assay. To further verify the binding site of this compound in vivo, IKK $\beta C 46 \mathrm{~A}$ transgenic (IKK $\beta^{\mathrm{C} 46 \mathrm{~A}}$ ) mice were generated. We found that ILG had a less potent immune-suppressive effect in homozygous IKK $\beta^{\text {c46A }}$ mice than IKK $\beta$ wild type (IKK $\beta$ wt) littermates with the delay-type hypersensitivity (DTH), suggesting that ILG cannot significantly suppress the inflammation due to the mutation of Cys-46 in the transgenic mice. Collectively, our findings indicate that the ILG inhibited T cell activation in vivo and in vitro via directly binding to IKK $\beta$ Cys46.

\section{INTRODUCTION}

With the advent of the Human Genome Project, the uniqueness of individuals and the importance of personalized medicine have been realized to provide more appropriate healthcare. However, it offers the challenges about identification of the accurate binding site of drugs. In the present study, the immunosuppressive effect, underlying mechanism and molecular binding site of isoliquiritigenin (ILG; 2',4',4-trihydroxychalcone (Figure 1A)) have been investigated on activated T lymphocytes in vitro and in vivo.

ILG, a member of the flavonoids, belongs to the chalcone family that is found in licorice, shallot and bean sprouts, and other medicinal herbs such as Sinofranchetia chinensis. The compound possesses various biological activities, including anti-inflammatory, antitumor and antihistamine effects in vitro and in vivo $[1,2]$. It also induces apoptosis in human glioma cells, human hepatoma cells and gastric cancer cells [4-7]. In addition, ILG reduces $\mathrm{H}_{2}$ histamine receptor $\left(\mathrm{H}_{2} \mathrm{R}\right)$ activity and gastric acid secretion thereby protecting against gastric mucosal lesion formation in a pylorus-ligated rat model [8]. Regarding its anti-inflammatory activities, ILG markedly suppresses lipopolysaccharides (LPS)-induced prostaglandin E2 ( $\left.\mathrm{PGE}_{2}\right)$ and cyclooxygenase-2 (COX-2) expression, nitric oxide (NO), interleukin-1 $\beta$ (IL-1 $\beta$ ), and tumor necrosis factors- $\alpha$ (TNF- $\alpha$ ) production, and induces heme oxygenase-1 (HO-1) expression through the extracellular signal-regulated kinase1/2 (ERK1/2) pathway in RAW 264.7 macrophages $[9,10]$. Recently, it has been reported that ILG blocks TNF- $\alpha$-induced expression of cell adhesion molecules in human endothelial cells by attenuating IкB kinase activity and ROS generation [11]. However, the effect of ILG on human T lymphocytes has not been well examined. 
It is known that $\mathrm{T}$ lymphocytes play important roles in the development of autoimmune and inflammatory diseases including rheumatoid arthritis, contact dermatitis and systemic lupus erythematosus. In this connection, suppression of $\mathrm{T}$ cell activation is a dominant strategy in the clinical management of autoimmune disorders. $\mathrm{T}$ lymphocyte proliferation relies on $\mathrm{NF}-\kappa \mathrm{B}$ activation, which facilitates the production of a series of proinflammatory cytokines, thereby aggravating autoimmune disease activity [12]. I $\mathrm{B}$ B kinase $\beta(\mathrm{IKK} \beta)$ is the key regulator of $\mathrm{NF}-\kappa \mathrm{B}$, hence then IKK $\beta$ has become an attractive therapeutic target for developing new drugs for treating inflammatory and autoimmune diseases.

In the current study, we investigated the immunosuppressive effect of ILG via inhibiting NF- $\kappa \mathrm{B}$ signaling in $\mathrm{T}$ lymphocytes. Molecular docking results predicted that IKK $\beta$ Cys-46 is probably the binding site of ILG. A competition assay and a kinase assay were performed to validate the virtual docking results. $\mathrm{IKK}^{\mathrm{C} 46 \mathrm{~A}}$ transgenic mice were also generated and used to demonstrate that IKK $\beta$ Cys-46 is involved in the suppressive effect of ILG in vivo.

\section{RESULTS}

\section{ILG inhibits human T lymphocyte proliferation and division}

Because proliferation is one of the hallmarks of $\mathrm{T}$ cell activation, we first investigated the inhibitory effect of ILG on the proliferation of human T cells purified from human peripheral blood mononuclear cells (PBMC), The results clearly demonstrated that ILG dose-dependently blocked $\mathrm{T}$ cell proliferation generated by PMA plus ionomycin (P/I) from 5 to $25 \mu \mathrm{M}$ (Figure 1B).

It has been reported that carboxyfluorescein diacetate succinimidyl ester (CFSE) could be used to monitor the number of cell divisions during proliferation and examine the relationship between proliferation and differentiation [13]. We therefore used CFSE to demonstrate the effect of ILG on cell division. The results showed that ILG significantly reduced the number of cell divisions at $10 \mu \mathrm{M}$ and almost totally blocked the number of cell divisions at $25 \mu \mathrm{M}$ (Figure $1 \mathrm{C}$ and Table 1).

\section{ILG blocks IL-2 and IFN- $\gamma$ secretion, as well as cell cycle progression in human $\mathrm{T}$ lymphocytes}

As mentioned above, $\mathrm{T}$ cell proliferation is one of the hallmarks of $\mathrm{T}$ cell activation; the other hallmark is the $\mathrm{T}$ cell growth factor secretion, including IFN- $\gamma$ and IL-2. We therefore further investigated the effect of ILG on cytokine secretion. As shown in Figure 2A and 2B, ILG significantly and dose-dependently suppressed the expression of both cytokines, which were greatly induced by $\mathrm{P} / \mathrm{I}$ in $\mathrm{T}$ lymphocytes. Cell cycle commitment determines cell proliferation and cytokine secretion, hence then we further examined the effect of ILG on the cell cycle progression. As shown in Figure 2C, cycling of $\mathrm{P} / \mathrm{I}$-mediated cells was progressing from $\mathrm{G} 0 / \mathrm{G} 1$ to $\mathrm{S}$ and G2-M phase, whereas it was blocked at the G0/G1 phase by ILG at $25 \mu \mathrm{M}$.

\section{ILG suppresses CD69 and CD25 expression on human $\mathrm{T}$ lymphocyte surfaces}

T cell surface activation markers, including CD69, CD25 and CD71, accompany the entry of T cells through G0/G1 to S phase. It has been demonstrated that ILG dosedependently arrested cell cycle from 5 to $25 \mu \mathrm{M}$; therefore, we further investigated the effect of ILG on the expression of $\mathrm{T}$ cell surface activation markers. The results showed that the expression of CD69, CD25 and CD71 were $56.7 \%, 36.8 \%$ and $51.3 \%$ on human $\mathrm{T}$ cells stimulated with P/I, whereas ILG reduced the expression of CD69 and CD25 to $12.3 \%$ and $5.4 \%$ (Figure $3 \mathrm{~A}-3 \mathrm{~B}$ ), respectively. Interestingly, we observed that ILG exhibited the opposite effect on CD71, showing it slightly up-regulated CD71 expression from $51.3 \%$ to $57.2 \%$ (Figure $3 \mathrm{C}$ ).

\section{ILG inhibits IKK-IкB $\alpha-\mathrm{NF}-\kappa \mathrm{B}$ signaling of human T lymphocytes}

NF- $\kappa \mathrm{B}$ signaling plays a crucial role in $\mathrm{T}$ cell activation [14]. We therefore evaluated the effect of ILG on $\mathrm{I} \kappa \mathrm{B} \alpha-\mathrm{NF}-\kappa \mathrm{B}$ signaling on human $\mathrm{T}$ lymphocytes. Considering the pivotal role of the transcriptional factor in the pathway, we examined whether ILG could inhibit the expression of NF- $\mathrm{kB}$ p 65 in the nucleus of T lymphocytes. As shown in Figure 4A, P/I stimulation could elevate p65 nuclear translocation, and ILG dose-dependently suppressed the p65 expression in the nucleus of T cells.

As p65 nuclear translocation is regulated by $\mathrm{I} \kappa \mathrm{B} \alpha$ phosphorylation and degradation, we investigated whether the inhibition of NF- $\kappa \mathrm{B}$ nuclear translocation results from a suppressive effect of ILG on I $\kappa \mathrm{B} \alpha$ phosphorylation and degradation. As shown in the upper panel of Figure 4B, ILG markedly suppressed I $\kappa \mathrm{B} \alpha$ degradation in a dose-dependent manner. To further determine whether the reduction of $I \kappa B \alpha$ degradation was a result of the inhibitory effect ILG on I $\mathrm{B} \alpha$ phosphorylation, we used the proteasome inhibitor N-acetyl-leucylleucyl-norleucinal (ALLN) to block the degradation of $\mathrm{I} \kappa \mathrm{B} \alpha$, and treated the cells by $\mathrm{P} / \mathrm{I}$ with or without ILG. The results showed that ILG strongly suppressed I $\mathrm{B} \alpha$ phosphorylation (Figure 4B, lower panel). In addition, it has been reported that stimulus-induced phosphorylation of $\mathrm{I} \kappa \mathrm{B} \alpha$ regulated by the IKK could be rapidly degraded by an ubiquitin-26S proteasome [14]. Considering the inhibition effect of ILG on the phosphorylation and degradation of I $\kappa \mathrm{B} \alpha$, we investigated the effect of ILG on IKK- $\alpha / \beta$ phosphorylation, and the results clearly showed 
Table 1: The effect of ILG on human $T$ cell division induced by $P / I$

\begin{tabular}{lccccc}
\hline \multirow{2}{*}{ Measure of proliferation } & Control & P/I & \multicolumn{3}{c}{ ILG $(\boldsymbol{\mu M})$} \\
\cline { 4 - 6 } & & & $\mathbf{5}$ & $\mathbf{1 0}$ & $\mathbf{2 5}$ \\
\hline \% Divided & $0.033 \pm 0.014$ & $0.437 \pm 0.065$ & $0.319 \pm 0.063$ & $0.120 \pm 0.019^{* *}$ & $0.011 \pm 0.004^{* *}$ \\
Div. Index & $2.382 \pm 1.489$ & $29.770 \pm 3.896$ & $22.600 \pm 3.470$ & $9.343 \pm 1.583^{* *}$ & $0.393 \pm 0.179^{* *}$ \\
\hline
\end{tabular}

Statistically significant differences with respect to $\mathrm{P} / \mathrm{I}$ are expressed as $* P<0.05$ and $* * P<0.01$. Data represent the mean \pm S.E.M. of three independent experiments

that ILG significantly and dose-dependently suppresses IKK $\alpha / \beta$ phosphorylation (Figure $4 \mathrm{C}$, upper panel). It was reported that IKK $\alpha$ regulates IKK $\beta$ kinase activity by phosphorylating IKK $\beta$ [15], and the effect of ILG on IKK $\alpha$ phosphorylation has been determined in the current study. Interestingly, ILG showed no significant effect on IKK $\alpha$ phosphorylation (Supplementary Figure S1), suggesting that the compound may have specific inhibitory effect on IKK $\beta$ phosphorylation.

Recent studies have demonstrated that the phosphorylation of $\mathrm{p} 65$ at Ser-536 by IKK $\beta$ contributes to $\mathrm{NF}-\kappa \mathrm{B}$ transcriptional activity [16]. Because ILG inhibits $\mathrm{NF}-\kappa \mathrm{B}$ nucleus translocation in an I $\kappa \mathrm{B}$-dependent manner, we investigated whether $\mathrm{p} 65$ phosphorylation suppressed by ILG is dispensable for NF- $\mathrm{BB}$ inhibition. The results show that $25 \mu \mathrm{M}$ ILG almost completely abolished phospho-Ser ${ }^{536}$ p65 levels by using an antibody specific for phospho-Ser536 p65 (Figure 4C, lower panel). Hence then, we determined whether ILG directly influences IKK $\beta$ and then suppressed phosphorylation of p65 and I $\mathrm{B} \alpha$ by a kinase assay. As shown in Figure 4D, the substrate of
IKK $\beta$, IкB $\alpha$, phosphorylation was suppressed by ILG as well as dihydromyricetin (DMY), the reference compound [18], implying that ILG inhibits IKK-I $\kappa \mathrm{B} \alpha-\mathrm{NF}-\kappa \mathrm{B}$ signaling of human $\mathrm{T}$ lymphocytes via the regulation of IKK $\beta$ activity.

\section{ILG suppresses IKK $\beta$ activity via binding to Cys-46}

To determine whether ILG inhibits IKK $\beta$ activity via directly binding to IKK $\beta$, we conducted molecular docking modeling to predict whether IKK $\beta$ is the molecular binding site of ILG. According to our results, the docking score of ILG with wild-type IKK $\beta$ and its C46A mutant are -12.23 and -11.76 , respectively. Figure $5 \mathrm{~A}$ illustrates the binding mode of ILG with IKK $\beta$, showing that ILG probably binds to IKK $\beta$ by hydrophobic, polar, and hydrogen bond interactions at Cys-46.

In the wild-type system, the hydrophobic groups of ILG form hydrophobic interactions with the side chains of Phe26, Gly27, Val29, Cys46, Leu50, Leu178, Cys179, and
A<smiles>O=C(/C=C/c1ccc(O)cc1)c1ccc(O)cc1O</smiles>

Isoliquiritigenin

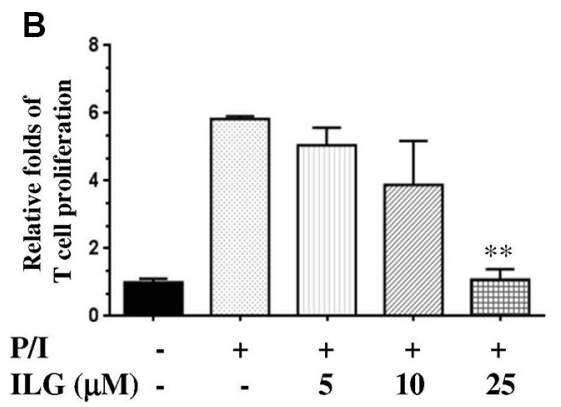

C

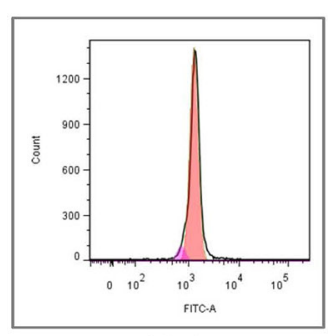

Ctrl

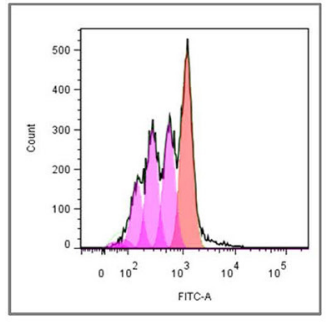

$\mathbf{P} / \mathbf{I}$

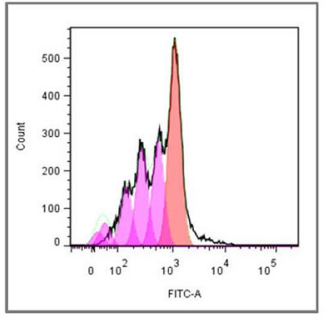

ILG $5 \mu M$

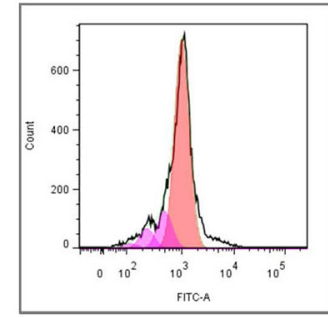

ILG $10 \mu M$

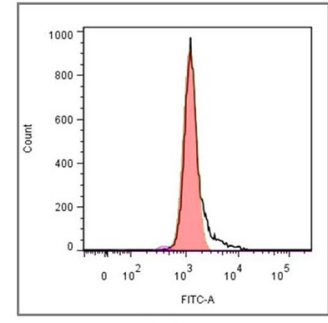

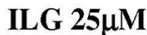

Figure 1: (A) The chemical structure of isoliquiritigenin (ILG). (B) The effect of ILG on human T cell proliferation induced by PMA plus ionomycin (P/I). (C) The effect of ILG on human T cell division induced by P/I. Statistically significant differences with respect to P/I are expressed as $* P<0.05$ and $* * P<0.01$. Data represent the mean \pm S.E.M. of three independent experiments. 
Thr180. The polar groups of ILG exhibit polar interactions with the side chains of Arg47, Gln48, Glu49, Lys53, Asn54, Arg57, Arg144, Glu177, and Glu181 (Figure 5A, left panel). In addition, ILG forms hydrogen bonds with the backbone of Gln48 and the side chains of Lys53, Arg57, and Leu178.

In the C46A mutant system, the binding mode of ILG in IKK $\beta$ was changed due to the C46A mutation of the protein. The hydrophobic groups of ILG form hydrophobic interactions with the side chains of Phe26, Gly27, Val29, Ala46, Leu50, Leu178, Cys179, and Thr180. The polar groups of ILG exhibit polar interactions with the side chains of Arg47, Gln48, Glu49, Lys53, Asn54, Arg57, Arg144, Glu177, and Glu181. In addition, ILG forms hydrogen bonds with the backbone of Gln48 and Glu177 and the side chains of Arg57, and Leu178 (Figure 5A, right panel). Collectively, the molecular docking results suggest that IKK $\beta$ Cys-46 is probably the binding site of ILG.

To further verify whether the inhibitory effect of ILG on IKK $\beta$ activity is associated with targeting of Cys-46 of the protein, single point mutant IKK $\beta$ constructs in which Cys-46 is replaced with alanine (A) (IKK $\beta$ $\mathrm{C} 46 \mathrm{~A})$ by site-directed mutagenesis were generated. The in vitro IKK $\beta$ kinase assay showed that IKK $\beta$ C46A has no response to ILG and DMY (Figure 5B). By contrast, berberine, which is reported to target IKK $\beta$ on Cys-179 [18], could suppress the IKK $\beta$ C46A activity, implying that Cys-46 is the target of ILG and DMY and not the target of berberine.

In our previous study, it was found that biotinylated-DMY (biotin-DMY) directly binds to IKK $\beta$ Cys46 via a covalent bond [18]. Considering the virtual computational docking results of ILG on IKK $\beta$, we utilized DMY-biotin, the validated probe, to determine whether ILG binding IKK $\beta$ C46A relies on covalent bonds. Therefore, a competition assay was performed with reducing SDS-PAGE. As shown in Figure 5C the signal of DMY-biotin could be easily found, whereas the DMY-biotin signal was significantly reduced in addition of ILG. Increases in ILG amount resulted in less DMY-
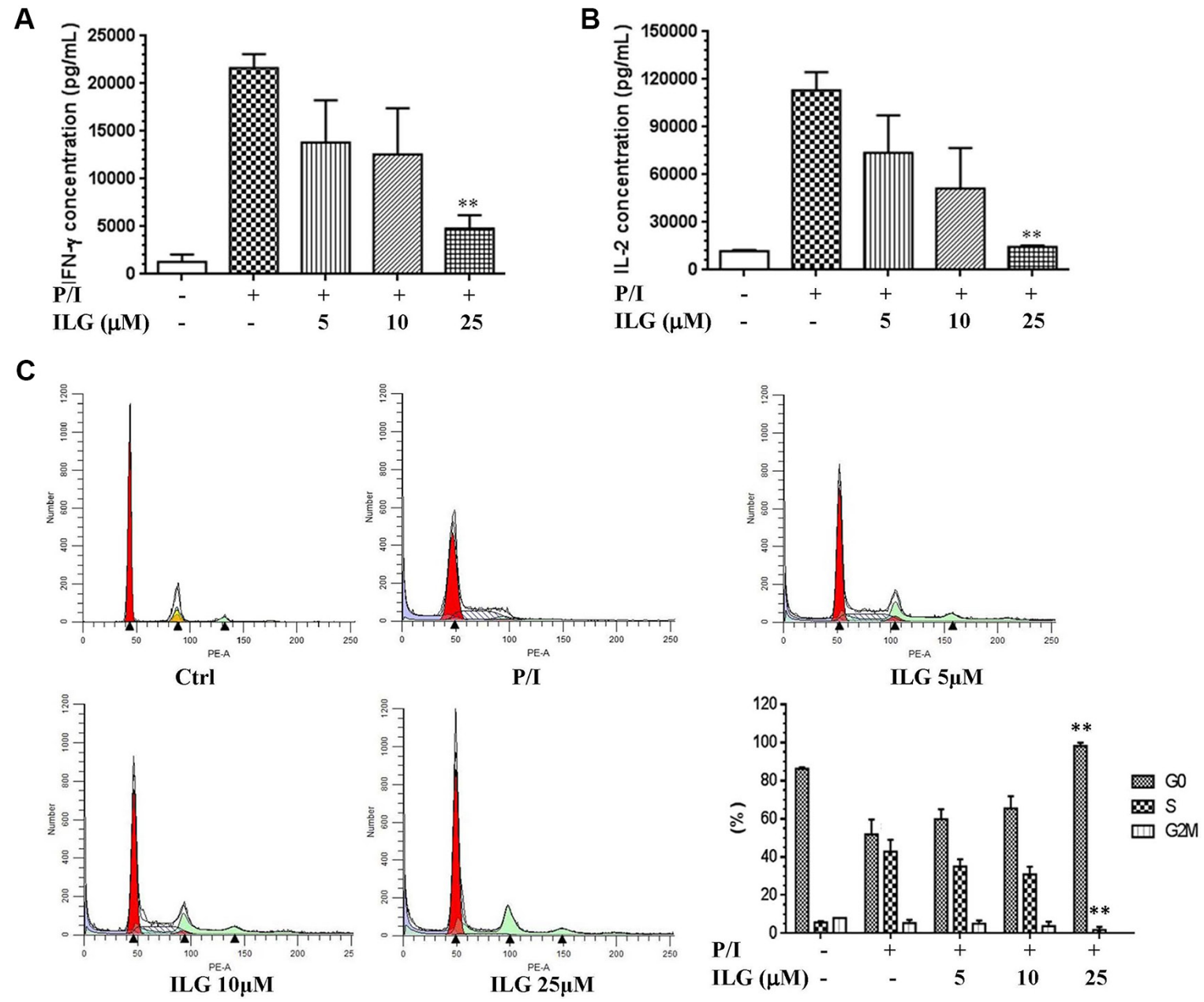

Figure 2: (A-B) The effect of ILG on IFN- $\gamma$ and IL-2 secretion on human T cells induced by P/I. (C) The effect of ILG on the human $\mathrm{T}$ cell cycle progression. Statistically significant differences compared to vehicle treatment are expressed as $* P<0.05$ and $* * P<0.01$. Data represent the mean \pm S.E.M. of three independent experiments. 
biotin signal, suggesting that the binding sites of ILG and DMY-biotin overlap. Collectively, these results show that IKK $\beta$ Cys 46 is the molecular target of ILG via covalent binding in vitro.

\section{The anti-inflammatory effect of ILG was abolished in IKK $\beta^{\mathrm{C} 46 \mathrm{~A}}$ transgenic mice}

The above results demonstrated that ILG possessed the immune-suppressive effect on human $\mathrm{T}$ cells via covalent binding IKK $\beta$ Cys46 in vitro. To further elucidate whether the immune-suppressive effect of ILG on the T cell activation is the result of mediating Cys46 of IKK $\beta$ in vivo, we generated IKK $\beta^{\mathrm{C} 46 \mathrm{~A}}$ transgenic mice and conducted a delay-type hypersensitivity (DTH) experiment, a mouse inflammatory model for atopic dermatitis triggered by $\mathrm{T}$ cells. The results showed that the immune-suppressive effect of ILG was less potent in homozygous IKK $\beta^{\mathrm{C} 46 \mathrm{~A}}$ mutant mice than in IKK $\beta$ wt mice (Figure 6A, Supplementary Table S1), which corroborates the in vitro results. The reference compound, dexamethasone, could significantly suppress edema and simultaneously induced the atrophy of thymus and spleen.
Interestingly, we observed that ILG could not reduce thymus spleen weight in both $\operatorname{IKK} \beta$ wt and $\operatorname{IKK} \beta^{\mathrm{C} 46 \mathrm{~A}}$ mutant mice (Figure 6B-6C). Collectively, these results suggest that IKK $\beta$ Cys- 46 is the molecular target of ILG to suppress $\mathrm{T}$ cell activation in vivo without significant toxicity.

\section{DISCUSSION}

Genomic variation plays an important role in the understanding of disease predisposition, biology and clinical response to therapy through effects on gene structure and expression. Advances in human genome research are opening the door to a new paradigm for practicing medicine that promises to transform healthcare [19]. Based on this concept, the personalized precision medicine, tailoring the practice of medicine to the individual, was recently initiated [19]. Under this premise, it is becoming more important to elucidate and verify the molecular target of the compounds being used for treatment. In recent years, medicinal plants are becoming an attractive source for drug discovery; for example, veregen, a mixture of flavonoids derived from

A
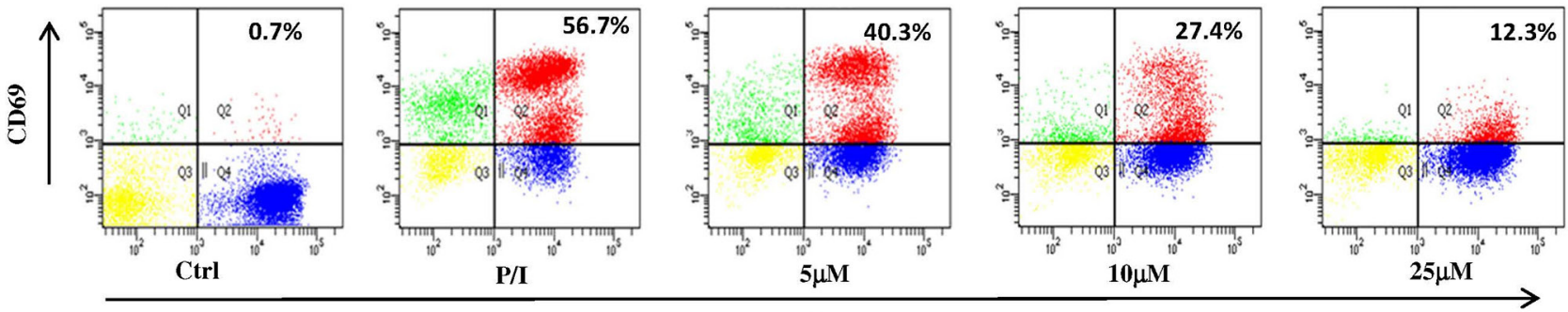

в
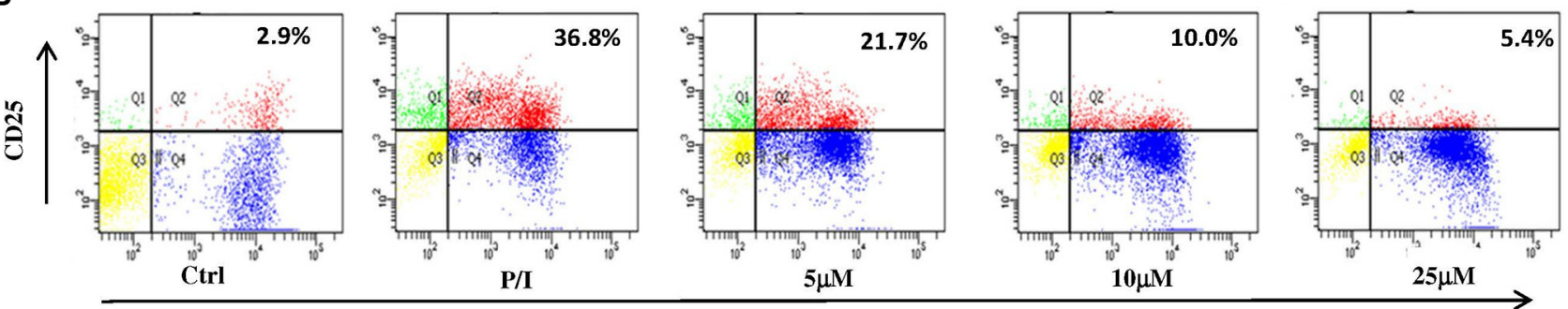

C
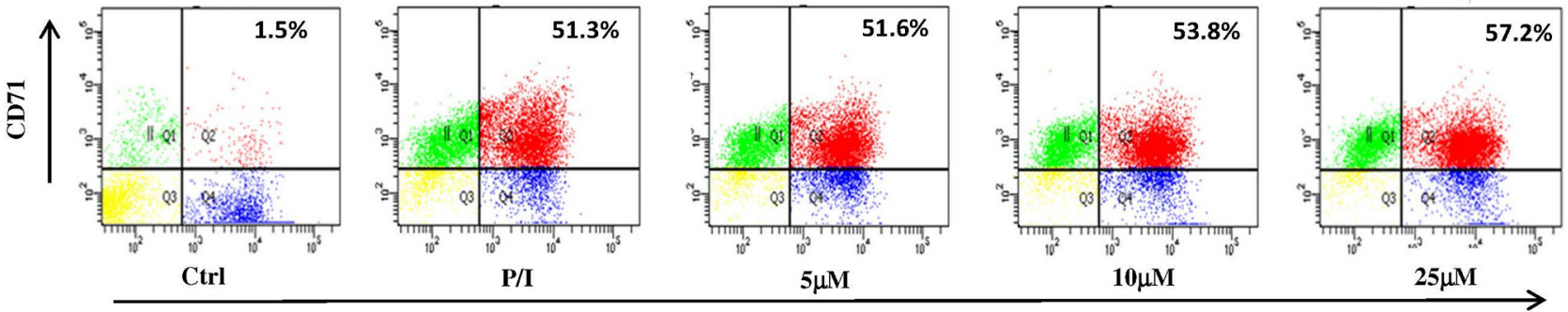

CD 3

Figure 3: (A-C) The effect of ILG on the expression of CD69, CD25 and CD71 on human T lymphocytes induced by P/I. Values represent percentages of the double stained cells. 
medicinal plants, was approved by the FDA in 2006 to treat external genital and perianal warts. Although herbal medicines provide an extensive resource for the development of new drugs, the underlying mechanisms and molecular targets of the most compounds have not been well expounded. For example, pseudolaric acid B, which is derived from Chinese medicinal herb, has not been identified for its molecular target on the suppression on T cells [20]. ILG is a major chemical component of licorice (Glycyrrhiza uralensis), which is one of the most commonly used to "harmonize" other ingredients in Chinese medical formulas [21, 22], and ILG is effective in the prevention and treatment of inflammatory conditions [23-24]. However, the function of ILG in T cells has not

A
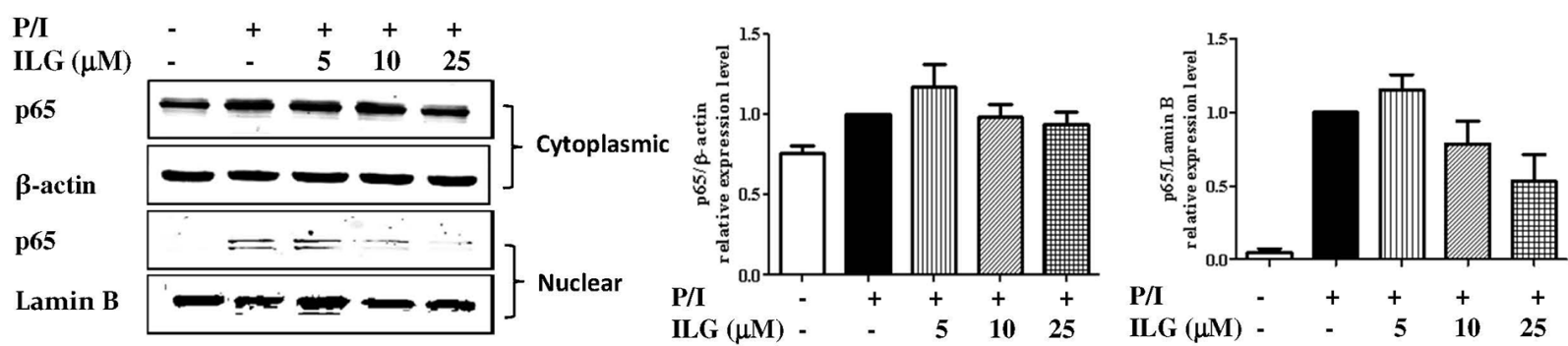

B
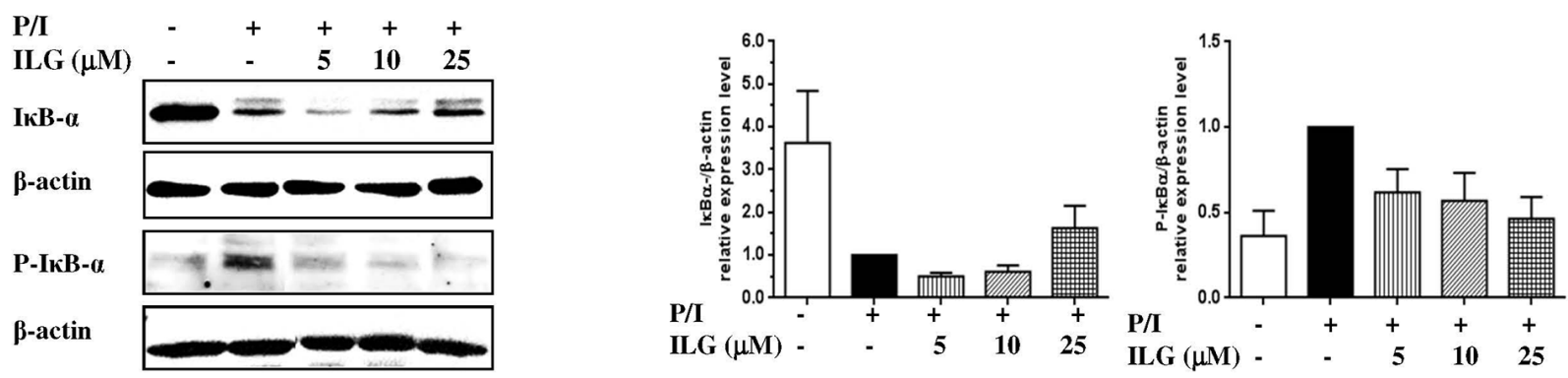

C
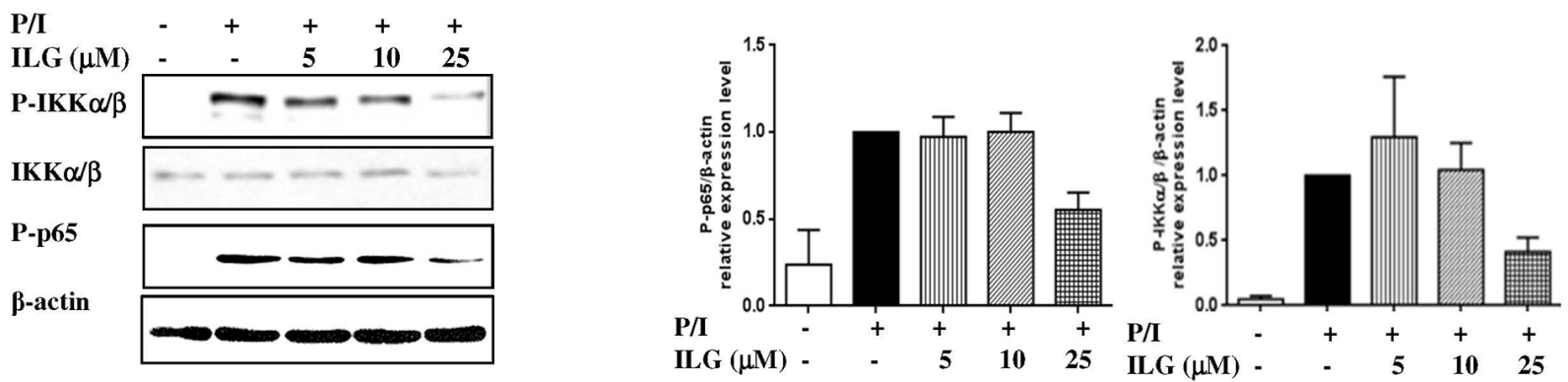

D
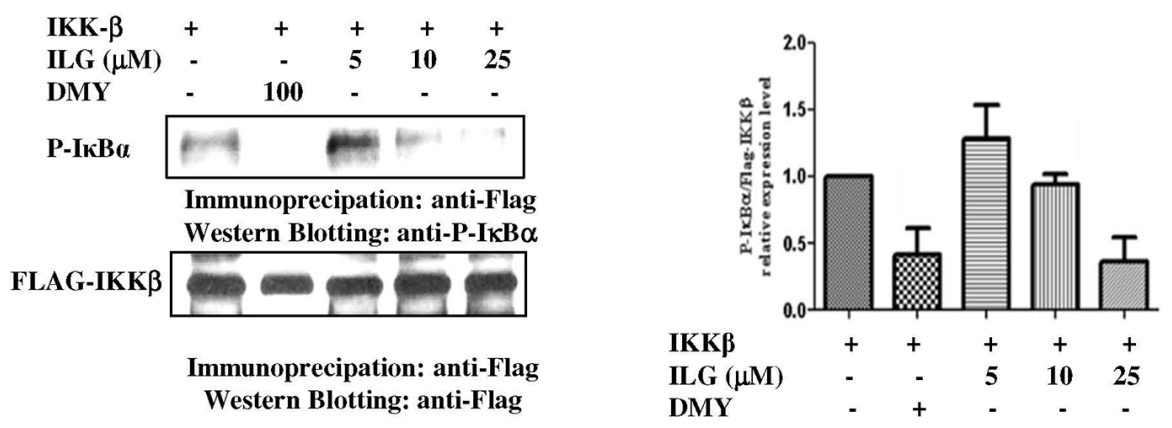

Figure 4: (A) The effect of ILG on the nuclear translocation of NF- $\kappa$ B subunit p65 in human T cells stimulated by P/I. (B) The effect of ILG on degradation and phosphorylation of I $\mathrm{I} B \alpha$ in human T lymphocytes stimulated by P/I. (C) The effect of ILG on IKK $\alpha / \beta$ phosphorylation and p65 phosphorylation in human T lymphocytes stimulated by P/I. (D) The effect of ILG on IKK $\beta$ activity. Data are representative of three independent experiments. 

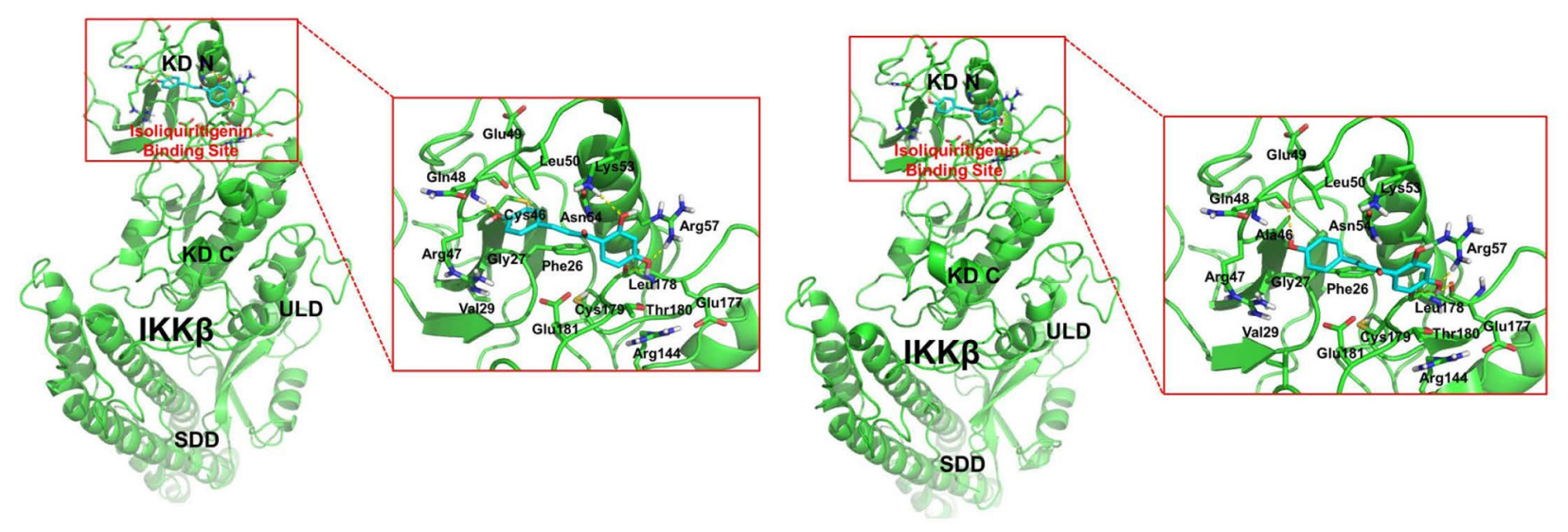

B

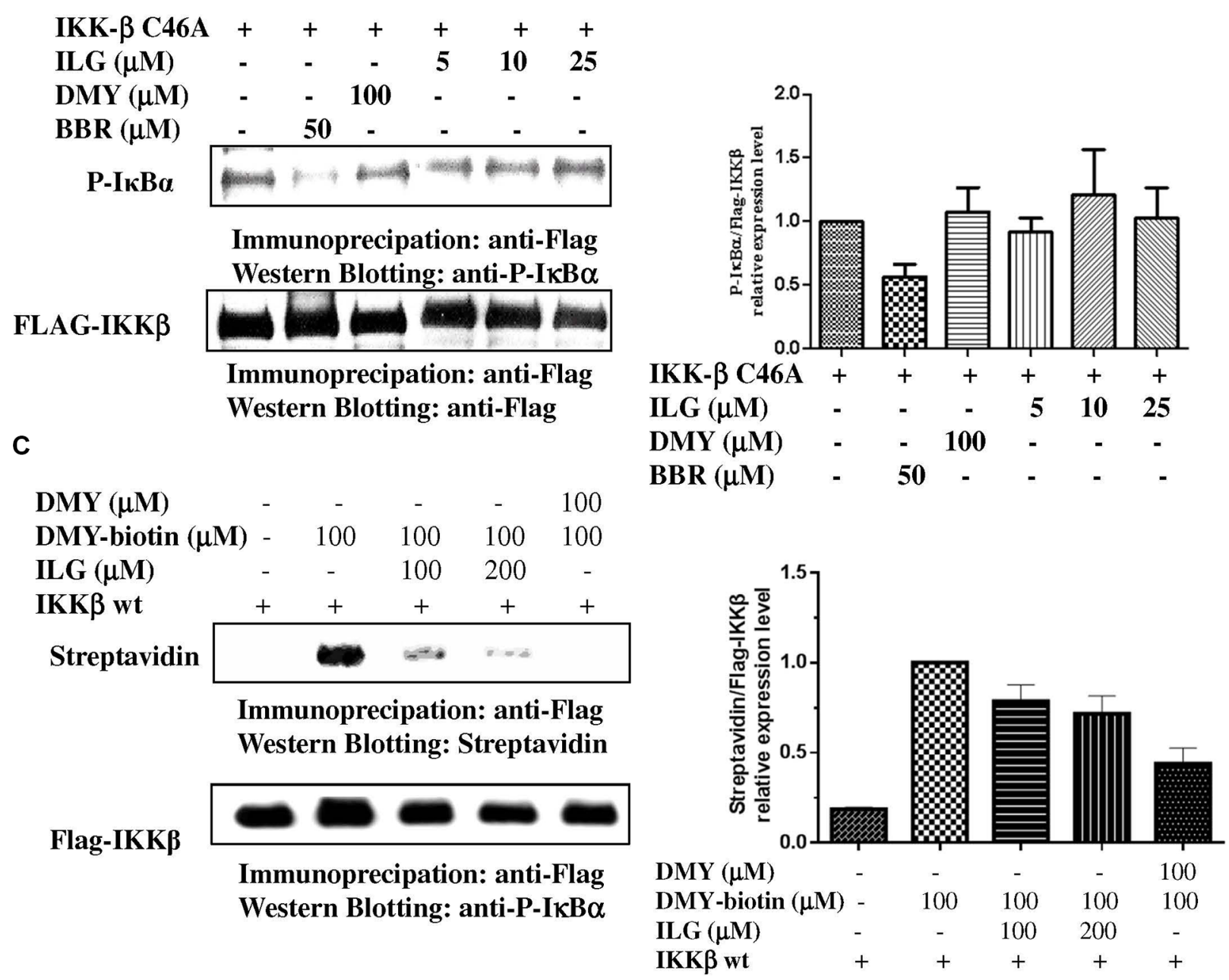

Figure 5: (A) Prediction of the molecular target of ILG by computational docking. High-precision computational model was applied to predict the approach that combines two elaborately built machine learning systems and multiple molecular docking tools to assess binding potentials of ILG against IKK $\beta$ involved in a complex molecular network. (B) The effect of ILG on the activity of IKK $\beta$ C46A. (C) Competitive binding experiments are used to elucidate the binding site of ILG at IKK $\beta$. Data are representative of three independent experiments. 
been studied. Our current study is the first to report the immune-suppressive effect, underlying mechanism, as well as molecular target of the compound in T cells.

In the present study, we have shown for the first time that ILG, not only inhibits human T lymphocyte proliferation and division stimulated by $\mathrm{PMA} /$ ionomycin in a dose-dependent manner, but it also reduces the PMA/ ionomycin-mediated human $\mathrm{T}$ lymphocyte cytokine secretion including IL-2 and IFN- $\gamma$, indicating that ILG could suppress $\mathrm{T}$ cell activation. We further found that ILG treatment could prevent cells from entering cell cycle, implying that ILG-induced cell cycle arrest might further contribute to the inhibition of T-cell proliferation and the production of the growth factors of T cells including IL-2 and IFN- $\gamma$. In addition, ILG could significantly attenuate CD69 and CD25 (IL-2 receptor) expression, and both of two markers were applied to evaluate the degree of immune responses. Interestingly, ILG slightly activates CD71, which is a marker of late stage T cell activation, implying that ILG probably has an influence on the early stages of $\mathrm{T}$ cell activation.

Because NF- $\kappa$ B suppresses CD25 expression, IL-2 production and T-cell proliferation, we further proposed that ILG might inhibit T-cell activation by blocking NF- $\kappa$ B signaling. Our expectation was confirmed that ILG could suppress the phosphorylation and degradation of $\mathrm{I} \kappa \mathrm{B} \alpha$, as well as NF- $\kappa$ B activity and phosphorylation of $\mathrm{p} 65$.

Since persistent activation of the NF- $\mathrm{B}$ signaling pathway is often associated with many inflammatory and autoimmune diseases, we therefore conducted intensive investigations on this signaling with ILG intervention. $\mathrm{IKK} \beta$ is a component of the IKK complex that serves as a protein subunit of I $\mathrm{KB}$ kinase, and plays a central role in the regulation of NF- $\kappa \mathrm{B}$ signaling in response to a diverse set of extracellular stimuli [26]. According to literature reports, IKK $\beta$ harbors four binding sites, including ATP, Ser177/181, Cys-179 and Cys-662/716 binding sites [27-30]. In our previous study, we found IKK $\beta$ can also offer a fifth binding site, Cys-46 of the protein [19], and it has been reported that a synthesized compound, ainsliadimer A, covalently binds to the conserved cysteine [31]. Ainsliadimer A could obviously inhibit $\mathrm{I} \kappa \mathrm{B} \alpha$ phosphorylation and degradation at $8 \mu \mathrm{M}$ in macrophage and cancer cell lines. Our current study demonstrated that ILG was able to significantly suppress NF- $\mathrm{B}$ signaling in T lymphocytes at $25 \mu \mathrm{M}$. Although the different cells were employed in the studies, it could be speculated that ainsliadimer A has more potential than ILG to inhibit the NF- $\mathrm{BB}$ signaling.
A

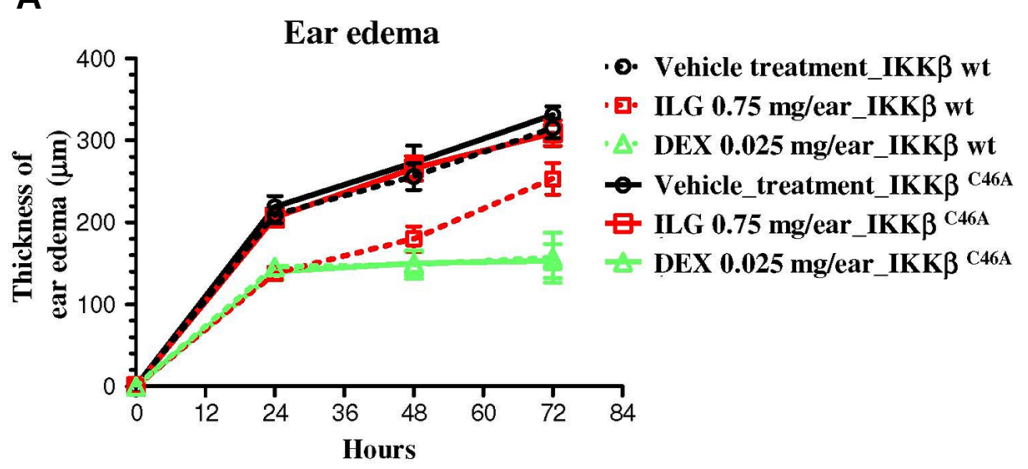

B

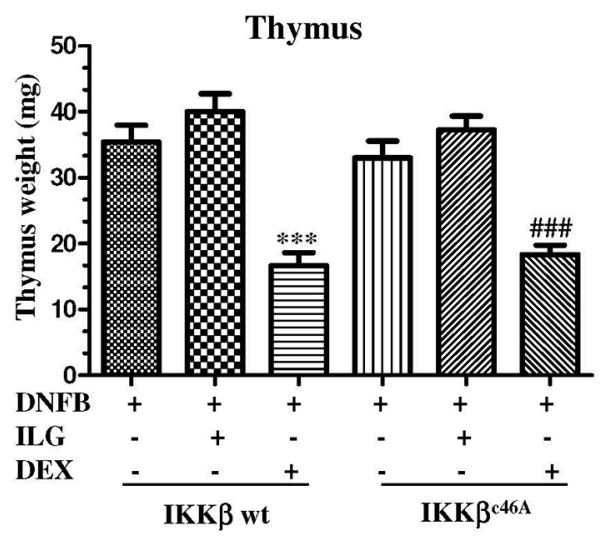

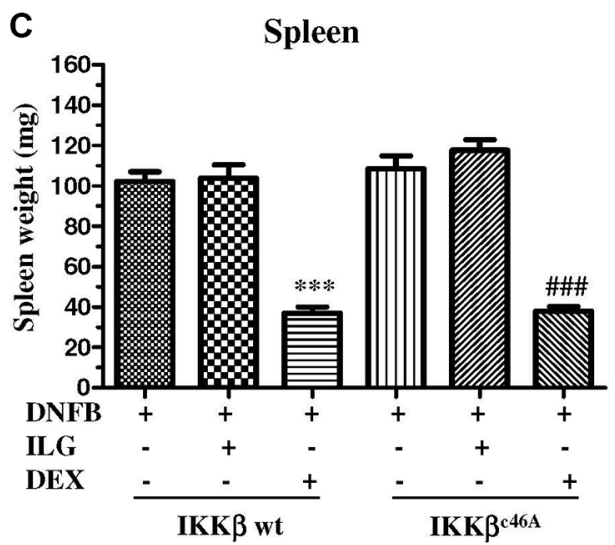

Figure 6: (A) The effect of ILG on the ear edema of the IKK $\beta^{\mathrm{C} 46 \mathrm{~A}}$ transgenic mice and wild-type littermates with delayed type hypersensitivity (DTH). (B-C) The effect of ILG on thymus and spleen weight of DTH IKK $\beta^{\text {C46A }}$ transgenic mice and wild-type littermates. Statistically significant differences with respect to the vehicle treatment in IKK $\beta$ wt and IKK $\beta^{\mathrm{C} 46 \mathrm{~A}}$ transgenic mice are expressed as $* P<0.05$, $* * P<0.01$ and $* * * P<0.001 ;{ }^{\#} P<0.05,{ }^{\# \#} P<0.01$ and ${ }^{\# \# \#} P<0.001$, respectively. 
Molecular docking programs are widely used as modeling tools for predicting ligand binding modes, as well as for a structure-based virtual screening approach [32]. To explore the binding site of ILG, we used computational tools for target identification and predicted that ILG probably binds to the Cys-46 of IKK $\beta$. Furthermore, we conducted a kinase assay to demonstrate that mutation of IKK $\beta$ Cys-46 could abrogate the suppressive effect of ILG on the activity of IKK $\beta$, which provided the evidence showing that Cys-46 of IKK $\beta$ is the binding site of ILG. Biotin-DMY has been identified binding to IKK $\beta$ Cys-46 in our previous study [18], and used as a probe to conduct a competition assay to demonstrate the molecular target of ILG on IKK $\beta$. We found that berberine, targeting on the Cys-179 of IKK $\beta$ [17], still has the ability to inhibit the kinase activity of IKK $\beta$ C46A and wt, and the competition assay provided the evidence to show that Cys-46 is not the binding site of berberine on IKK $\beta$. In concert with in vitro results, ILG has no significant immune-suppressive effect on IKK $\beta^{\mathrm{C} 46 \mathrm{~A}}$ transgenic mice, whereas it shows significant inhibitory effect on IKK $\beta$ wt mice in a DTH animal model, which is mediated by $\mathrm{T}$ cells. Collectively, ILG alleviated IKK $\beta$ activity via binding on Cys-46 and then reduced the degradation and phosphorylation of $I \kappa \mathrm{B} \alpha$, prevented $\mathrm{NF}-\kappa \mathrm{B}$ nuclear translocation, arrested human $\mathrm{T}$ cell cycle progression, cytokine secretion and $\mathrm{T}$ cell proliferation, eventually mediated the immune-suppressive effect on human $\mathrm{T}$ cells. In concert with in vitro results, the inhibitory effect of ILG was almost abolished completely in homozygous IKK $\beta^{\mathrm{C} 46 \mathrm{~A}}$ mutant mice. In summary, all of our results clearly demonstrate that the immunesuppressive effect of ILG in T cells in vivo and in vitro results from binding on the IKK $\beta$ Cys- 46 .

Because the MAPK family plays a crucial role in triggering the immune response, we also examined the effect of ILG on the signaling. Our results clearly showed that ILG has no obvious effect on MAPKs signaling (Supplementary Figure S2), indicating that ILG has more intensive effects on IKK $\beta-\mathrm{NF}-\kappa \mathrm{B}$ signaling than MAPKs. As ILG possesses a selective property on suppressing IKK $\beta$ activity, it is valuable to be further investigated on ILG as a lead compound into an immunosuppressive agent with clear molecular mechanisms for applications in inflammatory and autoimmune diseases in the future.

\section{MATERIALS AND METHODS}

\section{Drugs and reagents}

Isoliquiritigenin $>98 \%$ purity verified by HPLC was obtained from NanJing Zelang pharmaceutical R\&D Co., Ltd. (NanJing, China). Pan T Cell Isolation Kit II was purchased from MACs (CA, USA). Anti-human fluorescein isothiocyanate (FITC)-CD25, FITC-CD69 and FITC-CD71 antibodies, as well as phycoerythrin (PE)-CD3 antibody and other antibodies including that against NF- $\kappa$ B, were purchased from BD Pharmingen Inc. (San Diego, CA, USA). Phorbol 12-myristate 13-acetate (PMA), flag immunoprecipitation kit and flag antibody were obtained from Sigma-Aldrich (St Louis, MO, USA). Ionomycin were obtained from Calbiochem( La Jolla, CA, USA). Cell proliferation kit was obtained from Roche (Roche, Basel, Switzerland). The primary antibodies used in the current study were rabbit antibodies specific for P-IкB $\alpha$ (Ser32/36), P-IKK $\alpha / \beta$, P-JNK (Thr183/Try185), JNK, P-ERK1/2 (Thr220/Try204), ERK, P-p38 (Thr180/ Try182), p38, IKK- $\alpha / \beta$, p-IKK $\alpha / \beta$, P-p65 (Ser536) and $\mathrm{p}-\mathrm{I} \kappa \mathrm{B} \alpha(\mathrm{Ser} 32)$ provided by Cell Signaling Technologies (Beverly, MA, USA); while mouse antibodies specific for $\mathrm{I} \kappa \mathrm{B} \alpha$ (Cell Signaling, USA) and $\beta$-actin was provided by Santa Cruz (San Diego, CA, USA). Both IL-2 and IFN- $\gamma$ ELISA kit, as well as carboxyfluorescein diacetate succinimidyl ester (CFSE) were bought from Life Technologies. All other common chemicals and reagents were from Abcam (Cambridge, MA, USA) or SigmaAldrich unless otherwise specified.

\section{Human T lymphocyte isolation, purification and stimulation}

Human peripheral blood $\mathrm{T}$ lymphocytes were isolated from buffy coat according to the previous method [33]. In brief, the buffy coat provided by Macao Blood Transfusion Centre was mixed with normal saline, and then added to $50 \mathrm{ml}$ centrifuge tube containing FicollPague plus (Amersham Biosciences (Piscataway, USA). The mixture was separated to several layers after centrifuged at $350 \mathrm{~g}$ for $35 \mathrm{~min}$. The layer of mononuclear cells was collected, and purified by magnetic-activated cell sorting (MACs) pan T cell kit. $20 \mathrm{ng} / \mathrm{ml}$ PMA plus $1 \mu \mathrm{M}$ ionomycin $(\mathrm{P} / \mathrm{I})$ was employed in each experiment with different time intervals for different purpose.

\section{T lymphocyte proliferation and cytotoxicity assay}

The cell proliferation kit (Roche) was used to investigate the effect of ILG on the T cell proliferation according to the manufacturer's instruction. In brief, human T lymphocytes $\left(1 \times 10^{5} /\right.$ well $)$ were cultured in 96 well plates in triplicate in RPMI 1640 medium plus $10 \%$ FBS, and then stimulated with $20 \mathrm{ng} / \mathrm{ml}$ PMA plus $1 \mu \mathrm{M}$ ionomycin in the presence or absence of the compounds for $72 \mathrm{~h}$. Before the cells were collected, BrdU was added to the cells at final concentration of $10 \mu \mathrm{M}$, and incubated for another $14 \mathrm{~h}$. Finally, BrdU was determined by ELISA method according to the manual, and data were obtained from three independent experiments.

\section{Cell lines}

The cell lines HEK293 (human embryonic kidney) was obtained from American Type Culture Collection. The HEK293 cells were cultured in DMEM 
supplemented plus $10 \%$ FBS. The culture medium was supplemented with $100 \mathrm{U} / \mathrm{mL}$ penicillin and $100 \mu \mathrm{g} / \mathrm{mL}$ streptomycin.

\section{Enzyme-linked immunosorbent assay}

Enzyme-linked immunosorbent assay (ELISA) kit (Invitrogen, Carlsbad, CA, USA) was used to determine the amount of IL- 2 and IFN- $\gamma$ secreted by the activated human T lymphocytes. Briefly, cells $\left(1 \times 10^{5} /\right.$ well $)$ were incubated in the presence or absence of ILG at different concentrations, For stimulated with PMA plus inomycin, the cells were pretreated with ILG for $2 \mathrm{~h}$ at different concentrations, and then stimulated with $20 \mathrm{ng} / \mathrm{ml}$ PMA plus $1 \mu \mathrm{M}$ ionomycin for another $48 \mathrm{~h}$. Finally, the culture supernatants were collected, and then concentration of IL-2 and IFN- $\gamma$ in the supernatants was evaluated by ELISA method according to the manufacturer's instructions. Data were obtained from three independent experiments.

\section{T lymphocyte surface marker, intercellular protein, CFSE and cell cycle analysis}

The expressions of T lymphocyte activation markers, including CD25, CD69 and CD71, were measured by flow cytometry according to the previously described method [34]. The cells $\left(1 \times 10^{6} /\right.$ well $)$ was pretreated with ILG for $2 \mathrm{~h}$, followed by stimulated with PMA (20 ng/ml) plus ionomycin $(1 \mu \mathrm{M})$ [34]. To determine the expression of CD69, the cells were stimulated with PMA plus ionomycin for $24 \mathrm{~h}$; to evaluate the expressions of CD25 and CD71, the cells were incubated with stimulators for $48 \mathrm{~h}$. After collection, the cells were stained with indicated antibodies, and incubated for $30 \mathrm{~min}$ at room temperature avoiding from light, and then fixed with $4 \%$ paraformaldehyde (PFA). On the next day, samples were analyzed on FACS Calibur Flow Cytometer using CellQuest software. The separate tubes of cells stained with single-color antibodies for each of the flourochromes were severed as the compensation standards.

For analysis of cell cycle, human T lymphocytes $\left(10^{6} /\right.$ well) were pretreated with ILG for $2 \mathrm{~h}$ followed by stimulated with or without PMA $(20 \mathrm{ng} / \mathrm{ml})$ plus ionomycin $(1 \mu \mathrm{M})$ for $72 \mathrm{~h}$. After collected, washed by PBS and fixed by $70 \%$ ethanol, the cells were stained by PI (Propidium Iodide, BD Pharmingen,San Diego, USA) for $30 \mathrm{~min}$ at room temperature, and then the cell cycle was analyzed by flow cytometry [35].

To monitor the number of cell divisions during proliferation, the division tracking dye carboxyfluorescein diacetate succinimidyl ester (CFSE) was used according to the previous method [36]. In brief, the cells were incubated with pre-warmed $\mathrm{PBS} / 0.1 \% \mathrm{BSA}$ at a final concentration of $1 \times 10^{6}$ cells $/ \mathrm{mL}$. Two $\mu \mathrm{L}$ of $5 \mu \mathrm{M}$ stock CFSE solution was added to the cells at final working concentration of $10 \mu \mathrm{M}$. After incubated with the dye at $37^{\circ} \mathrm{C}$ for $10 \mathrm{~min}$, the cells were added ice-cold culture medium and incubated for $5 \mathrm{~min}$ to quench the staining. The cells were washed by fresh medium and treated with ILG for $2 \mathrm{~h}$, followed by stimulation with PMA/ionomycin for another 5 days, and finally analyzed by flow cytometer.

\section{Analyses of cellular protein expressions by using Western blotting}

To evaluate the phosphorylation form of $\mathrm{I} \kappa \mathrm{B} \alpha$, human T lymphocytes $\left(4 \times 10^{6} /\right.$ well $)$ were pretreated with ILG at different concentrations followed by $100 \mu \mathrm{g} / \mathrm{ml}$ $\mathrm{N}$-acetyl-leucyl-leucyl-norleucinal (ALLN) (Calbiochem, USA) for $60 \mathrm{~min}$, and the cells were then incubated with PMA $(20 \mathrm{ng} / \mathrm{ml})$ plus ionomycin $(1 \mu \mathrm{M})$ for another $60 \mathrm{~min}$. For determination of $\mathrm{I} \kappa \mathrm{B} \alpha, \mathrm{P}-\mathrm{IKK} \alpha / \mathrm{b}, \mathrm{P}-\mathrm{p} 65$ and $b$-actin from whole cellular proteins, the human $\mathrm{T}$ lymphocytes $\left(4 \times 10^{6} /\right.$ well $)$ were stimulated with PMA plus ionomycin for $1 \mathrm{~h}$ after pre-incubated with different concentrations of ILG for $120 \mathrm{~min}$. The T lymphocytes were harvested and lysed with lysis buffer (Sigma) with $1 \times$ protease inhibitor mix (Roche) to prepare the whole cellular lysates. For NF- $\kappa$ B nuclear translocation assay, the cytoplasmic and nuclear fractions of $\mathrm{T}$ cells were prepared by using NE-PER ${ }^{\mathrm{TM}}$ Nuclear and Cytoplasmic Extraction (thermo fisher scientific, USA). The whole cellular or nucleus extracts were then subjected to electrophoresis in $10 \% \mathrm{SDS} / \mathrm{PAGE}$ and to immunoblotting according to the previous method [37].

\section{Transfection and immunoprecipitation}

The transfection assay was preformed according to the manufacturer's instruction of lipofectamine LTX (invitrogen, USA). In brief, HEK293 cells were seeded in $1.5 \mathrm{ml}$ of DMEM growth media plus $10 \% \mathrm{FBS}$ at $5 \times 10^{5}$ cells per well. Five hundred microliter Opti-MEM Reduced Serum Media containing $1.25 \mu \mathrm{g}$ of DNA was added to the cells to be transfected, and then $1.25 \mu \mathrm{l}$ of PLUS was added into the above diluted Opti-MEM:DNA solution, gently mixed and incubated for another $5 \mathrm{~min}$ at room temperature. Subsequently, lipofectamine LTX ${ }^{\mathrm{TM}}$ Reagent was added into the above solution, and then mixed gently and incubated $30 \mathrm{~min}$ at room temperature to form DNA-lipofectamine LTX Reagent complexes. Finally, $500 \mu \mathrm{l}$ of the DNA-lipofectamine LTX Reagent complexes was directly added to each well containing cells and mixed gently. The cells were incubated at $37^{\circ} \mathrm{C}$ in a $\mathrm{CO}_{2}$ incubator for $24 \mathrm{~h}$.

Immunoprecipitation was used to pull down IKK $\beta$ recombinant protein from HEK 293 cells overexpressing Flag-IKK $\beta$ according to the manufacture's instruction of Flag tagged protein immunoprecipitation Kit (Sigma). Briefly, HEK293 cells were harvested and lysed by incubation with lysis buffer for $15 \mathrm{~min}$ on ice, after transfected with Flag-IKK $\beta$ for $24 \mathrm{~h}$. The lysate was collected by centrifugation for $10 \mathrm{~min}$ at $12,000 \times \mathrm{g}$, cell lysates were then added to the resin provided by the 
kit. The resin was collected by centrifuging for $30 \mathrm{~s}$ at $8200 \times \mathrm{g}$ after agitated for overnight at $4^{\circ} \mathrm{C}$. The FlagIKK $\beta$ was eluted by competition with $3 \times$ Flag peptide, and stored at $-80^{\circ} \mathrm{C}$ or further conduct IKK $\beta$ kinase assay and competition assay.

\section{IKK $\beta$ kinase assay}

To determine the effect of ILG on IKK $\beta$ activity, the IKK $\beta$ kinase assay was performed. Briefly, I $\mathrm{I} B \alpha$ substrate supplied by Enzo Life Science (Farmingdale, NY, USA), Flag-IKK $\beta$ recombinant protein, and ATP were incubated with or without ILG at $30^{\circ} \mathrm{C}$ for $30 \mathrm{~min}$. The mixture was analyzed by $10 \%$ SDS-polyacrylamide gel electrophoresis (SDS-PAGE), and then electro-transferred onto nitrocellulose membranes. The nitrocellulose membranes were incubated with P-IкB $\alpha$ (Ser32/36) for overnight at $4{ }^{\circ} \mathrm{C}$ after blocked by $5 \%$ dried milk for $60 \mathrm{~min}$. Next day, the membranes were further incubated with HRP-conjugated secondary antibodies for $60 \mathrm{~min}$, and developed using ECL Western Blotting Detection Reagents (Life Technologies).

\section{Competition assay}

Flag-IKK $\beta$ wild type (wt) was precipitated from HEK 293 overexpressing Flag-IKK $\beta$, and incubated with ILG or DMY for $1 \mathrm{~h}$ and then $100 \mu \mathrm{M}$ DMY-biotin was added to the mixture. Subsequently, the proteins were separated by SDS-PAGE and transferred to nitro-cellulose membranes. After blocking with BSA and washing with PBST, the membranes were incubated with streptavidin horseradish peroxidase for $1 \mathrm{~h}$ and developed with enhanced chemiluminescence. Finally, the membranes were incubated with anti-Flag antibody to evaluate the expression of Flag-IKK $\beta$.

\section{Computational methods}

The initial 3D structure of ILG was built using the Molecule Builder module incorporated in MOE software. The structure was then subjected to energy minimization and partial charges calculation with Amber99 force field. The crystal structure of wild-type inhibitor of $\kappa B$ kinase $\beta$ (IKK $\beta$ ) was retrieved from Protein Data Bank (PDB ID code 3RZF [38]). On the basis of the wild type protein structure, the structure of IKK $\beta$ with C46A mutant was obtained by performing single point mutation with Rotamer Explorer in MOE software. To prepare the protein for molecular docking, the protein structure was subjected to partial charges calculation and energy minimization with Amber99 force field. Energy minimization was terminated when the root mean square gradient falls below $0.05 \mathrm{kcal} /(\mathrm{mol} \cdot \AA)$.

The prepared proteins and ligand were introduced for molecular docking. The docking site was identified by using Site Finder in MOE software. The identified binding site including residue Cys46 was chosen as the binding site for molecular docking according to our experiment. In molecular docking, the Triangle Matcher placement method and London dG scoring function were used. A total of 30 docking poses were generated for the ligand and the pose with the best binding mode was selected for further analysis.

\section{IKK- $\beta^{\mathrm{C} 46 \mathrm{~A}}$ transgenic mice}

The IKK- $\beta^{\mathrm{C} 46 \mathrm{~A}}$ transgenic mice were generated by Shanghai Biomodel Organism Science \& Technology Development Co., Ltd. (Shanghai, China). The transgenic mice were validated by PCR and gene sequencing. The IKK- $\beta^{\mathrm{C} 46 \mathrm{~A}}$ mice have been backcrossed to C57BL/ 6 for 6 generations in our experiments, and the wild-type littermates were served as control. They were kept under 12:12 $\mathrm{h}$ cycle of light with ad libitum access to food and drink. All mice were kept under specific pathogen-free conditions in the animal care facility at Guangdong Provincial Hospital of Traditional Chinese Medicine. Animal care and experiments were conducted in accordance with the Laboratory Animal Research Committee Guidelines of Guangdong Provincial Hospital of Traditional Chinese medicine.

\section{DTH animal model}

Mice were sensitized through topical application onto their shaved abdomens of $20 \mu \mathrm{l}$ of a $0.5 \%$ DNFB in 4:1 acetone/olive oil mixture on days 0 and 1(sensitization phase). Five days after sensitization, the mice were challenged on day 6 with application of $20 \mu 1$ of a $0.5 \%$ DNFB in $4: 1$ acetone/olive oil mixture to the left inner and outer surfaces of the mice (elicitation phase). Ear thickness measurements of both the treatment and control/blank groups were taken with an electronic digital caliper at 24, 48 and $72 \mathrm{~h}$ after challenge and the response quantitated as the difference in the thickness of the challenged ear.

\section{Statistical analysis}

Data are expressed as means \pm S.E.M. One-way ANOVA or Student's $t$-test was used to determine the significance of difference; a value of $p<0.05$ was considered statistically significant.

\section{ACKNOWLEDGMENTS}

We thank Prof Tom Gilmore (Boston University) for the gift of IKK $\beta$ wild type plasmids. Australia Innovation Patent No.: 2015100662; granted on 28, May 2015. 


\section{CONFLICTS OF INTEREST}

The authors state no conflicts of interest.

\section{GRANT SUPPORT}

This work was supported by FDCT grants from the Science and Technology Development Fund of Macao (Project code 081/2013/A3).

\section{REFERENCES}

1. Jhanji V, Liu H, Law K, Lee VY, Huang SF, Pang CP, Yam GH. Isoliquiritigenin from licorice root suppressed neovascularisation in experimental ocular angiogenesis models. Br J Ophthalmol. 2011; 95:1309-1315.

2. Kang SW, Choi JS, Choi YJ, Bae JY, Li J, Kim DS, Kim JL, Shin SY, Lee YJ, Kwun IS, Kang YH. Licorice isoliquiritigenin dampens angiogenic activity via inhibition of MAPK-responsive signaling pathways leading to induction of matrix metalloproteinases. J Nutr Biochem. 2010; 21:55-65.

3. Kwon GT, Cho HJ, Chung WY, Park KK, Moon A, Park JH. Isoliquiritigenin inhibits migration and invasion of prostate cancer cells: possible mediation by decreased JNK/AP-1 signaling. J Nutr Biochem. 2009; 20:663-676.

4. Yamazaki S, Morita T, Endo H, Hamamoto T, Baba M, Joichi Y, Kaneko S, Okada Y, Okuyama T, Nishino H, Tokue A. Isoliquiritigenin suppresses pulmonary metastasis of mouse renal cell carcinoma. Cancer Lett. 2002; 183:23-30.

5. Zhou GS, Song LJ, Yang B. Isoliquiritigenin inhibits proliferation and induces apoptosis of U87 human glioma cells in vitro. Mol Med Rep. 2013; 7:531-536.

6. Hsu YL, Kuo PL, Lin LT, Lin CC. Isoliquiritigenin inhibits cell proliferation and induces apoptosis in human hepatoma cells. Planta Med. 2005; 71:130-134.

7. Ma J, Fu NY, Pang DB, Wu WY, Xu AL. Apoptosis induced by isoliquiritigenin in human gastric cancer MGC-803 cells. Planta Med. 2001; 67:754-757.

8. Kim DC, Choi SY, Kim SH, Yun BS, Yoo ID, Reddy NRP, Yoon HS, Kim KT. Isoliquiritigenin Selectively Inhibits H2 Histamine Receptor Signaling. Mol Pharmacol. 2006; 70:493-500.

9. Lee SH, Kim JY, Seo GS, Kim YC, Sohn DH. Isoliquiritigenin, from Dalbergia odorifera, up-regulates anti-inflammatory heme oxygenase- 1 expression in RAW264.7 macrophages. Inflamm Res. 2009; 58:257-262.

10. Takahashi T, Takasuka N, Iigo M, Baba M, Nishino H, Tsuda H, Okuyama T. Isoliquiritigenin, a flavonoid from licorice, reduces prostaglandin E2 and nitric oxide, causes apoptosis, and suppresses aberrant crypt foci development. Cancer Sci. 2004; 95:448-453.

11. Kumar S, Sharma A, Madan B, Singhal V, Ghosh B. Isoliquiritigenin inhibits IkappaB kinase activity and ROS generation to block TNF-alpha induced expression of cell adhesion molecules on human endothelial cells. Biochem Pharmacol. 2007; 73:1602-1612.

12. Hayden MS, West AP, Ghosh S. NF-[kappa]B and the immune response. Oncogene. 2006; 25:6758-6780.

13. Kim J, Cha YN, Surh YJ. A protective role of nuclear factor-erythroid 2-related factor-2 (Nrf2) in inflammatory disorders. Mutat Res-Fund Mol. 2010; 690:12-23.

14. Sakurai H, Suzuki S, Kawasaki N, Nakano H, Okazaki T, Chino A, Doi T, Saiki I. Tumor necrosis factor-alphainduced IKK phosphorylation of NF-kappaB p65 on serine 536 is mediated through the TRAF2, TRAF5, and TAK1 signaling pathway. J Biol Chem. 2003; 278:36916-36923.

15. Yamamoto Y, Yin MJ, Gaynor RB. IkappaB kinase alpha (IKK $\alpha$ lpha) regulation of IKK $\beta$ eta kinase activity. Mol Cell Biol. 2000; 20:3655-3666.

16. Sakurai H, Chiba H, Miyoshi H, Sugita T, Toriumi W. IkappaB kinases phosphorylate NF-kappaB p65 subunit on serine 536 in the transactivation domain. J Biol Chem. 1999; 274:30353-30356.

17. Pandey MK, Sung B, Kunnumakkara AB, Sethi G, Chaturvedi MM, Aggarwal BB. Berberine modifies cysteine 179 of I $\mathrm{K} \mathrm{\alpha} \alpha$ kinase, suppresses nuclear factor- $\kappa \mathrm{B}$-regulated antiapoptotic gene products, and potentiates apoptosis. Cancer Res. 2008; 68:5370-5379.

18. Li T, Wong VK, Jiang ZH, Jiang SP, Liu Y, Wang TY, Yao XJ, Su XH, Yan FG, Liu J, Leung EL, Yi XQ, Wong YF, et al. Mutation of cysteine 46 in IKK-beta increases inflammatory responses. Oncotarget. 2015; 6:31805-31819. doi: 10.18632/oncotarget.5567.

19. Ohman A, Eriksson A, Olofsson C. One-trial learning and superior resistance to extinction of autonomic responses conditioned to potentially phobic stimuli. J Comp Physiol Psychol. 1975; 88:619-627.

20. Li T, Wong VK, Yi XQ, Wong YF, Zhou H, Liu L. Pseudolaric acid B suppresses T lymphocyte activation through inhibition of NF-kappaB signaling pathway and p38 phosphorylation. J Cell Biochem. 2009; 108:87-95.

21. Kong LD, Zhang Y, Pan X, Tan RX, Cheng CH. Inhibition of xanthine oxidase by liquiritigenin and isoliquiritigenin isolated from Sinofranchetia chinensis. Cell Mol Life Sci. 2000; 57:500-505.

22. Kape R, Parniske M, Brandt S, Werner D. Isoliquiritigenin, a strong nod gene- and glyceollin resistance-inducing flavonoid from soybean root exudate. Appl Environ Microbiol. 1992; 58:1705-1710.

23. Cuendet M, Guo J, Luo $\mathrm{Y}$, Chen S, Oteham CP, Moon RC, van Breemen RB, Marler LE, Pezzuto JM. Cancer Chemopreventive Activity and Metabolism of Isoliquiritigenin, a Compound Found in Licorice. Cancer Prev Res. 2010; 3:221-232.

24. Chan SC, Chang YS, Wang JP, Chen SC, Kuo SC. Three new flavonoids and antiallergic, anti-inflammatory constituents from the heartwood of Dalbergia odorifera. Planta Med. 1998; 64:153-158. 
25. Vaya J, Belinky PA, Aviram M. Antioxidant constituents from licorice roots: isolation, structure elucidation and antioxidative capacity toward LDL oxidation. Free Radic Biol Med. 1997; 23:302-313.

26. Irelan JT, Murphy TJ, DeJesus PD, Teo H, Xu D, GomezFerreria MA, Zhou Y, Miraglia LJ, Rines DR, Verma IM, Sharp DJ, Tergaonkar V, Chanda SK. A role for IкB kinase 2 in bipolar spindle assembly. P Natl Acad Sci. 2007; 104:16940-16945.

27. Dinkova-Kostova AT, Talalay P. Direct and indirect antioxidant properties of inducers of cytoprotective proteins. Mol Nutr Food Res. 2008; 52:S128-S138.

28. Hayes JD, McMahon M, Chowdhry S, DinkovaKostova AT. Cancer chemoprevention mechanisms mediated through the Keap1-Nrf2 pathway. Antinxis Redox Sign. 2010; 13:1713-1748.

29. Komatsu M, Kurokawa H, Waguri S, Taguchi K, Kobayashi A, Ichimura Y, Sou YS, Ueno I, Sakamoto A, Tong KI. The selective autophagy substrate p62 activates the stress responsive transcription factor Nrf2 through inactivation of Keap1. Nat Cell Biol. 2010; 12:213-223.

30. Park SY, Lee SW, Shin HK, Chung WT, Lee WS, Rhim BY, Hong KW, Kim CD. Cilostazol enhances apoptosis of synovial cells from rheumatoid arthritis patients with inhibition of cytokine formation via $\mathrm{Nrf}^{-}$linked heme oxygenase 1 induction. Arthritis Rheumatol. 2010; 62:732-741.

31. Rushworth SA, MacEwan DJ, O'Connell MA. Lipopolysaccharide-induced expression of NAD (P) H: quinone oxidoreductase 1 and heme oxygenase- 1 protects against excessive inflammatory responses in human monocytes. J Immunol. 2008; 181:6730-6737.
32. Cross JB, Thompson DC, Rai BK, Baber JC, Fan KY, Hu Y, Humblet C. Comparison of Several Molecular Docking Programs: Pose Prediction and Virtual Screening Accuracy. J Chem Inf Model. 2009; 49:1455-1474.

33. Ghittoni R, Patrussi L, Pirozzi K, Pellegrini M, Lazzerini PE, Capecchi PL, Pasini FL, Baldari CT. Simvastatin inhibits T-cell activation by selectively impairing the function of Ras superfamily GTPases. FASEB J. 2005; 19:605-607.

34. Leung CY, Liu L, Wong RN, Zeng YY, Li M, Zhou H. Saikosaponin-d inhibits $\mathrm{T}$ cell activation through the modulation of PKCtheta, JNK, and NF-kappaB transcription factor. Biochem Bioph Res Co. 2005; 338:1920-1927.

35. Sancho R, Macho A, de La Vega L, Calzado MA, Fiebich BL, Appendino G, Munoz E. Immunosuppressive activity of endovanilloids: N-arachidonoyl-dopamine inhibits activation of the NF-kappa B, NFAT, and activator protein 1 signaling pathways. J Immunol. 2004; 172:2341-2351.

36. Hawkins ED, Hommel M, Turner ML, Battye FL, Markham JF, Hodgkin PD. Measuring lymphocyte proliferation, survival and differentiation using CFSE timeseries data. Nat Protocols. 2007; 2:2057-2067.

37. Li T, Yan F, Wang R, Zhou H, Liu L. Shikonin Suppresses Human T Lymphocyte Activation through Inhibition of IKK beta Activity and JNK Phosphorylation. Evid-Based Compl Alt. 2013; 2013:379536.

38. Xu G, Lo YC, Li Q, Napolitano G, Wu X, Jiang X, Dreano M, Karin M, Wu H. Crystal structure of inhibitor of kappaB kinase beta. Nature. 2011; 472:325-330. 